\title{
Neonatal Seizure
}

National Cancer Institute

\section{Source}

National Cancer Institute. Neonatal Seizure. NCI Thesaurus. Code C118507.

Abnormal hypersynchronous electrical activity in the brain of a newborn which may be associated with stereotyped movements or autonomic changes. 